УДК 159.9:130.123.4

doi: 10.15330/ps.9.1.88-95

Аліна Парасєй-Гочер

Інститут педагогічної освіти і освіти дорослих НАПН України

orion-ap@ukr.net

\title{
ДО ПОБУДОВИ ПСИХОЛОГІЧНОЇ МОДЕЛІ ДУХОВНОГО РОЗВИТКУ ПІДЛІТКІВ- СИРІТ У ЗАКЛАДАХ ІНТЕРНАТНОГО ТИПУ
}

\begin{abstract}
Стаття присвячена одній з актуальних проблем сучасних психолого-педагогічних досліджень в ирарині духовності та духовного розвитку особистості. Стан розробки наукових досліджень з проблеми духовного розвитку особистості та психологічного супроводу дітей сиріт і дітей, позбавлених батьківського піклування, спонукав до теоретичного обтрунтування психологічної моделі процесу духовного розвитку підлітків - вихованиів державних закладів інституалізації. Аргументовано, щзо для духовного становлення, формування та реалізації позитивних емочійно-почуттєвих станів, пізнавальних інтересів, иіннісних орієнтацій підлітків-сиріт доцільним $є$ застосування духовно-особистісного підходу, який дозволяє розглядати духовний розвиток підлітків як проиес взаємодії зовнішніх (соияіально-психологічних) та внутрішніх (індивідуально-психологічних) особливостей сиріт у закладах інтернатного типу. Особлива увага автором приділена визначенню та обтрунтуванню методологічних принципів: принцииу ісрархічності (формування впорядкованої системи структурних компонентів духовності), позитивності (иінність особистості підлітків, акцент на позитивному досвіді та орієнтації на майбутнє) та принции духовної особистісної взаємодії (створення атмосфери довіри, співробітництва «психолог-дитина»). Відповідно до духовно-особистісного підходу визначено механізми духовного розвитку підлітків-сиріт (ідентифікації, децентрації, рефлексії, трансценденції та усвідомлення буттєвої єдності), а також етапи процесу духовного розвитку сиріт: етап опанування духовними почуттями; духовного пізнання та самопізнання (рефлексія); духовного самовдосконалення (формування морально-духовних вчинків); етап спрямованості духовного зростання (орієнтації на духовні ідеали, смисли, иүінності). Виокремлено чотири компоненти духовності: почуттєво-емоційний, пізнавальний, морально-поведінковий та ціннісно-смисловий. Зазначено, щчо кожен з етапів у процесі духовного розвитку підлітків спрямований на формування певного компоненту духовності. Вказано на те, щзо основна ідея психологічної моделі процесу духовного розвитку підлітків-сиріт полягає в тому, щзо етапи та компоненти духовності взаємопов'язані: в процесі формування одного етапу та компоненту відбувається становлення наступного. Визначено проблеми та перспективи подальших досліджень духовного розвитку.
\end{abstract}

Ключові слова: підлітковий вік, психологічні особливості сиріт, духовний розвиток, принципи духовноорієнтованого підходу, етапи прочесу духовного розвитку, психологічна модель.

Постановка проблеми. Відсутність позитивного життєвого досвіду, морально-духовних орієнтирів, нестача духовних знань і переконань та ін. є причинами духовного голоду молодих людей. Тому проблема духовного розвитку і виховання підростаючого покоління сьогодні $\epsilon$ однією з ключових.

Варто зазначити, що, незважаючи на форсування деінституалізації інтернатних закладів в Україні, проблема духовного розвитку дітей-сиріт, та дітей, позбавлених батьківського піклування, особливо гостро стоїть перед педагогами та психологами. Адже поки діти $\epsilon$ вихованцями державних закладів інтернатного типу, всі, хто має до них причетність, несуть відповідальність не тільки за фізичний та психічний, але й за гармонійний духовно-моральний розвиток дітей та підлітків-сиріт. У зв'язку з цим одним 3 найважливіших завдань нашого суспільства $є$ підтримка у створенні умов для духовного розвитку дітей та підлітків-сиріт, аби зцілити їх «зранений» внутрішній світ, розкрити свою індивідуальність, сформувати позитивне ставлення до себе та інших людей, розкрити творчий потенціал тощо.

Аналіз останніх досліджень і публікацій свідчить про те, що проблема морального та духовного розвитку особистості протягом останніх років активно досліджується. Так, над вивченням духовності та духовного розвитку особистості працювали Г.О. Балл, І. Д. Бех, Л. I. Божович, М. Й. Боришевський, І. С. Булах, Ж. О. Маценко, О. В. Мудрик, Е. О. Помиткін, М. В. Савчин, Т. М. Титаренко та ін. 
Методологічним підгрунтям для побудови психологічної моделі духовного розвитку підлітків-сиріт виступають основні наукові концептуальні положення про структуру особистості (Г. С. Костюк, С. Д. Максименко, В. В. Рибалка, С. Л. Рубінштейн), особистісний розвиток підлітків (Л. І. Божович, Л. С. Виготський, Д. Б. Ельконін, І. С. Кон, О. М. Леонтьєв, Д. I. Фельдштейн), природу соціального сирітства та умов проживання дітей у закладах інтернатного типу (Г. М. Бевз, І. В. Дубровіна, М. Ю. Кондратьєв, В. С. Мухіна, Л. В. Петрановська, Г. М. Прихожан, Н. М. Толстих, Л. М. Шульга) та процес духовного розвитку особистості (І. Д. Бех, М. Й. Боришевський, Н. А. Коваль, О. І. Климишин, Н. В. Павлик, Е. О. Помиткін, М. В. Савчин).

Мета статті полягає у теоретичному обгрунтуванні психологічної моделі процесу духовного розвитку підлітків-сиріт у закладах інтернатного типу.

Виклад основного матеріалу. Розробка психологічної моделі процесу духовного розвитку підлітків-сиріт потребує глибокого і всебічного аналізу цього феномену. Психологічна модель процесу духовного розвитку підлітків-сиріт повинна бути спрямована на актуалізацію їхнього духовного потенціалу через прийняття своєї особистості та інших людей, наявності духовно-моральних переконань, позитивну смисложиттєву орієнтацію, наявність духовних ідеалів (прикладів духовної самореалізації та самовдосконалення), орієнтацію на духовні смисли (усвідомлення себе в цьому світі) та цінності, гармонійну спільну діяльність 3 дорослими й однолітками.

Важливим аспектом в розробці психологічної моделі $\epsilon$ аналіз психологічної сутності процесу духовного розвитку підлітків-сиріт в контексті базових методологічних підходів та принципів психологічної науки.

У грунтовних дослідженнях В. В. Рибалки виокремлено основні методологічні підходи до дослідження процесу становлення та розвитку особистості [9, с. 72]: індивідуальнопсихологічний, соціально-психологічний, віковий, діяльнісний, системно-психологічний та особистісний підходи.

На думку дослідника духовного розвитку Е. О. Помиткіна, наведені вище підходи не охоплюють цілком феномени духовності та процес духовного розвитку особистості, оскільки мають бути враховані наукові уявлення про духовність, ії смислоутворювальні категорії Краси, Добра, Істини та Любові, актуалізації духовного потенціалу особистості [8, с. 90]. Тому, поєднуючи філософсько-психологічні погляди на процес духовного розвитку особистості, цей науковець обгрунтував духовного-особистісний підхід, в якому «розкриваються смислоутворювальні категорії духовності та актуалізуються вищі психічні функції особистості, свідомості, самосвідомості та волі у процесі розвитку іiі ідеалів, цінностей та смислів» [7, с. 32].

Відтак в нашому науковому дослідженні психологічних особливостей духовного розвитку підлітків-сиріт доцільним вважаємо спиратися на духовно-особистісний підхід, запропонований Е. О. Помиткіним [8]. Адже, як зазначає автор, «специфічною ознакою цього підходу $є$ те, що розгляд феноменів духовного розвитку здійснюється невід'ємно від психологічної структури особистості, з усіма притаманними їй внутрішніми процесами» [8, с. 90]. Тому завдяки обраному нами духовно-особистісному підходу духовний розвиток підлітківсиріт зорієнтований на гармонійний процес духовного становлення, формування та реалізації пізнавальних можливостей, ціннісних орієнтацій, актуалізацію духовного потенціалу підлітків.

Спираючись на духовно-особистісний підхід, в якому філософські погляди на духовність інтегруються з психологічними уявленнями про особистість, іiі структуру та внутрішні процеси у нашому дослідженні визначено такі принципи:

- принцип ієрархічності (Е. О. Помиткін, Н. В. Павлик) передбачає гармонійне формування взаємопов'язаних почуттєво-естетичної, пізнавальної, морально-поведінкової, ціннісно-смислової сфер підлітків, які забезпечують повноцінний розвиток духовного потенціалу сиріт; 
- принцип позитивності (Н. В. Павлик) в контексті духовно-особистісного підходу знаходить відображення у розвитку налаштування підлітків-сиріт на позитивне прийняття себе та інших; підтримання позитивних психічних станів з високим ступенем творчої енергії, ефективними навичками саморегуляції в проблемних життєвих ситуаціях;

- принщип духовної особистісної взаємодї (В. Г. Панок) спрямований на процес створення атмосфери довіри, співробітництва та взаєморозуміння між підлітками-сиротами та дорослими.

Розглянемо детальніше вагомі в контексті розробки нашої моделі методологічні принципи.

Поняття принципу (від лат. - «початок, основа», від грецького - «переконання») у філософському розумінні трактується як підстава, що охоплює певну сукупність фактів, або основне положення висунутої теорії, вчення, світогляду [2].

Отже, сутність принцииу ієрархічності (впорядкованості, підпорядкування) духоноособистісного підходу розглядається Е. О. Помиткіним як принцип, в процесі якого вибудовується «Я-концепція» особистості та впорядковуються іiі мотиви, спрямовані на розв'язання найважливіших проблем буття, досягається гармонійне співвідношення фізичної, емоційно-почуттєвої та інтелектуальної сфер [7, с. 32-33].

Розвиток людської психіки розглядається у працях Л. С. Виготського, О. М. Леонтьєва, Б. Ф. Ломова, С. Л. Рубінштейна та ін. Так, психіка розглядається Б. Ф. Ломовим як цілісна система внутрішніх та зовнішніх взаємозв'язків. Відповідно до принципу ієрархічності дослідник зазначає, що «людина постає як складна жива система, життєдіяльність якої забезпечується на різних, але взаємопов'язаних між собою рівнях функціонування» [1].

Згідно з Н. В. Павлик принцип ієрархічності характеризує впорядкованість між рівнями системи особистості, в якій «психічні явища вищого ієрархічного рівня інтегрують у собі якості нижчих рівнів, тобто підструктури вищого психічного рівня виступають провідними регуляторами усієї системи» [3, с. 147-148].

Принцип ієрархічності в процесі духовного розвитку підлітків-сиріт означає формування впорядкованої системи структурних компонентів духовності підлітків-сиріт шляхом проходження певних етапів духовного розвитку.

Оскільки процес духовного розвитку підлітків - вихованців інтернатних закладів спрямований на гармонійне та послідовне формування компонентів духовності, для розробки психологічної моделі вважаємо важливим окремо приділити увагу принципу позитивності. Цей методологічний принцип є одним із провідних принципів сучасного напрямку в психологічній науці - інтегративної психології, основна ідея якої полягає у цілісному баченні людини, ії фізичного, соціального та духовного зростання, розкритті іiі внутрішнього потенціалу, творчості, пробудження вищих станів свідомості та особистісних ресурсів [9]. Основною функцією принципу позитивності є фокусування особистості на позитивному досвіді.

О. Г. Уманська зазначає, що коли людина здатна ототожнити себе в теперішньому часі з тією, якою вона себе бачила в минулому та бачить у своєму майбутньому, то це є запорукою позитивного розвитку особистості, іiі повноцінного життєздійснення [11, с. 78]. Оскільки підлітки-сироти переважно мають порушення емоційно-почуттєвого зв'язку з дорослими, що в результаті постає головною причиною емоційної депривації, то в них найчастіше формується дисгармонійний образ світу. В численних дослідженнях емоційної сфери дітей-сиріт та дітей, позбавлених батьківського піклування, Л. М. Шипіцина стверджує, що «в умовах емоційної депривації дитина виявляється нездатною до конструктивних соціальних контактів, адже дефіцит досвіду спілкування посилює іiі емоційну і соціальну депривацію» [12, с. 15].

У свою чергу дослідниця духовно-моральних утворень у структурі характеру в юнацькому віці Н. В. Павлик виділяє принцип позитивності, який орієнтує на визнання безумовної цінності особистості іншої людини, вміння бачити позитив навіть у проблемних ситуаціях [3, с. 147-148]. Завдяки досвіду позитивних емоційних проявів, таких як 
доброзичливість, емпатія тощо, відбувається духовно-моральна гармонізація характеру молодих людей [4, с.11].

У контексті зазначених психологічних особливостей підлітків-сиріт, що виражені в емоційній, інтелектуальній, соціально-комунікативній сферах, та чинників, які впливають на їх духовний розвиток, важливим є принцип духовної особистісної взаємодї. Саме врахування цього принципу необхідне для розробки та обгрунтування психолого-педагогічної програми духовного розвитку дітей та підлітків-сиріт у закладах інтернатного типу.

Сутність принципу духовної особистісної взаємодії (або духовно й особистісно орієнтована взаємодія) полягає в іiі практичному значенні, що передбачає глибинну психологічну взаємодію, спрямовану на внутрішній світ особистості. Принцип духовної особистісної взаємодії втілює в себе як принцип гуманізму, так і принцип індивідуальнісного підходу [9; 8; 5]. Визначаючи сутність принципу гуманізму, В. Г. Панок акцентує увагу саме на правилах, відображених в етичному кодексі практичного психолога [8; 5, с. 12]. За принципом гуманізму, «або гуманістичного підходу до людини, усі види діяльності у практичній роботі мають бути домірними іï об'єктові, виходити 3 інтересів і прав людини, захисту іiі особистісного суверенітету, всебічного розвитку їі самобутності» $[9 ; 5$, с. 31$]$.

Щодо принципу індивідуальнісного підходу, науковець наголошує на тому, що особистість постає перед практичним психологом у своїй унікальності, неповторності, індивідуальності $[9$, с. $69 ; 5$, с. 31]. В. В. Рибалка доповнює, що в процесі взаємодії практичного психолога та клієнта «психологічні проблеми є своєрідними, унікальними, одиничними, що потребує від практичного психолога кожного разу творчого підходу до особистості, розгортання творчої психологічної діяльності» [9, с. 69].

Зважаючи на нелегкий життєвий досвід підлітків-сиріт, які перебувають у закладах інтернатного типу, чимало зусиль докладається психологом, соціальним педагогом або педагогічним працівником для створення та забезпечення сприятливих умов виховання й розвитку дітей-сиріт, оптимізацію психолого-педагогічного процесу [6]. Нам близька наукова позиція низки дослідників (Г. В. Бевз, Ж. В. Петрочко, О. Р. Поляновська, Т. І. Шульга та ін.) щодо соціальної, педагогічної та психологічної специфіки роботи у закладах інтернатного типу, які одностайно наголошують, що попри загальну соціально-педагогічну підтримку (захист прав дітей в оволодінні освітою, профорієнтація, підготовка до самостійного життя та ін.) мають бути створені необхідні психологічні умови для гармонійного саморозвитку й самовдосконалення дітей та підлітків, посилення моральної мотивації, формування життєвих духовно-моральних цінностей [6].

Таким чином, характерною ознакою принципу духовної особистісної взаємодії $є$ гармонія міжособистісних взаємин, спілкування в системі «практичний психолог-педагог-дитина» має відбуватися в атмосфері довіри, співробітництва, в постійному діалозі, відкрито тощо. В процесі духовної особистісної взаємодії підлітки - вихованці закладів інтернатного типу залучаються до різноманітних видів психолого-педагогічної діяльності, в яких розкривають і реалізують свій духовний потенціал.

М. В. Савчин зазначає, що «духовний розвиток людини - тривалий процес, пов'язаний із перешкодами, небезпеками, процесами глибокого духовного очищення, повної трансформації, пробудження здібностей, розвитку свідомості» [10, с. 125].

Духовний розвиток - це перш за все динамічний процес, що реалізується відповідними психологічними механізмами. Це - ідентифікація, децентрація, рефлексія, трансценденція та усвідомлення буттєвої єдності. При цьому ідентифікація - це ототожнення з високодуховними особистостями, 3 власним духовним «Я»; децентрація - звільнення від егоцентризму, орієнтація особистості на потреби інших; рефлексія - здатність звертати увагу на свій внутрішній світ; трансценденція - прагнення особистості до абсолютно досконалого, ідеального, що сприяє осягненню таких чеснот, як життєлюбство, людинолюбство, любов до Батьківщини, до рідного краю; усвідомлення буттєвої єдності - це можливість осягнути 
людиною себе часткою єдиного цілого - природи, Всесвіту. Так, «у результаті актуалізації психологічних механізмів духовного розвитку, - зазначає Е. О. Помиткін, - відбувається активний розвиток ціннісно-смислової сфери, упорядкування ідеалів, смислів і цінностей, гармонізація духовних дисонансів» [8, с. 188-189].

Е. О. Помиткін [8] визначає духовний розвиток як «процес свідомого самовдосконалення особистості», а в якості духовних світоглядних орієнтирів -ідеалів, цінностей і смислів виступають категорії краси, добра та істини, які науковець об'єднав у психологічній моделі процесу духовного розвитку. В структурному складі моделі Е. О. Помиткін детально розглянув психологічні механізми духовного розвитку особистості (ідентифікація, децентрація, рефлексія, трансценденція, усвідомлення буттєвої єдності),

Основна ідея психологічної моделі процесу духовного розвитку підлітків-сиріт полягає у тому, що етапи та компоненти духовності взаємопов'язані між собою і становлення одного етапу та компоненту є необхідною умовою якісного розгортання наступного.

Етап опанування духовними почуттями. Процес формування духовних почуттєвоестетичних станів супроводжується вмінням відрізняти, розуміти і виражати свої почуття підлітками (як позитивні, так і негативні); усвідомити власні індивідуальні емоційно-почуттєві прояви; установлювати стосунки з оточенням, аналізувати свої стосунки, бачити не тільки себе, але й інших, а також установлюючи емоційно близькі стосунки, водночас захищати свої кордони. Завдяки розвитку емпатійних здібностей підліток вчиться розуміти іншого. Як результат сформованості цього етапу - актуалізація потреби підлітків в розумінні власних почуттів, іншої людини; сформованість естетичних почуттів; розвиток емпатійних здібностей; емоційна стійкість; сприймання краси навколишнього.

Eman духовного пізнання та самопізнання. Цей етап спрямований на особистісний розвиток та самопізнання підлітків - рефлексивного складника духовного розвитку. Стимулювання розуміння підлітками питання «Хто я і яке моє місце в цьому світі»; поняття добра й зла. Вихованці інтернатних закладів знайомляться з методами самопізнання, вивчають власні можливості, сильні і слабкі прояви свого характеру. Результатом сформованості цього етапу $\epsilon$ актуалізація потреби в духовному самовдосконаленні підлітків, сформованість понять та уявлень про духовні якості через усвідомлення та розуміння власних можливостей й осмислення своїх вчинків. Формуються духовно-моральні норми й уявлення, зростає цінність власного життя. Відбувається самовизначення у поняттях добра та зла.

Eman духовного самовдосконалення (опанування морально-комунікативними навичками). Формуються навички прогнозування власних дій та аналізу їхніх наслідків, виробляється конструктивне ставлення до помилок. Етап орієнтований на розвиток моральноповедінкового компонента духовності підлітків. Як результат сформованості цього етапу активізація здібностей підлітків до духовного розвитку, духовної активності. Застосування отриманих знань і переконань, здатність до самостійного ухвалення морально обгрунтованих рішень. Розвиток відповідальності за своє життя, свою діяльність та поведінку. Усвідомлення власних можливостей, позитивне і відповідальне ставлення до життя, зріле ціннісне самовизначення.

Eman орієнтації духовного зростання характеризується спрямованістю духовного життя підлітків на високі духовні ідеали, смисли та цінності. Розширення уявлень підлітків про загальнолюдські цінності, розвиток духовних ціннісних орієнтацій (виконують функції регуляції і спрямування поведінки людини). Самоствердження - актуалізація підлітком духовно-моральних мотивів в організації власної діяльності й поведінки. Самовдосконалення актуалізація мотивації особистісного росту підлітків через прагнення бути кращими, наближення до духовного ідеалу. Самоактуалізація - вища форма саморозвитку, здатність виявити в собі духовний потенціал і керуватися ним у житті. Активізація прояву духовної волі, здатність діяти всупереч деструктивному пресингу щодо мотивів діяльності та поведінки. 
Аналіз досліджуваної літератури з проблем психічного розвитку підлітків-сиріт та духовного розвитку особистості, зважаючи на філософські категорії краси, добра та істини, дозволив виявити змістовні характеристики, які зумовили компонентний склад духовності підлітків-сиріт - вихованців інтернатних закладів:

- почуттєво-естетичний компонент духовності визначається сформованістю позитивних емоційно-естетичних станів, здатністю до емоційного відгуку;

- пізнавальний компонент духовності підлітків визначається обсягом та сформованістю понять та уявлень про духовні якості особистості;

- морально-поведінковий компонент духовності характеризується вольовою саморегуляцією та духовно-моральною мотивацією, відповідальністю за власні дії та вчинки;

- ціннісно-смисловий компонент духовності визначається актуалізацією зв’язків між минулим, теперішнім та майбутнім підлітків, спрямованістю на духовні цінності.

Отже, аналізуючи методологічні основи дослідження духовного розвитку дітей та підлітків-сиріт, можна зробити висновок, що у дослідженнях науковців ще не реалізовано експериментальне визначення поетапної та компонентної класифікації духовного розвитку сиріт підліткового періоду онтогенезу.

Висновки і пропозиції. Таким чином, на теоретичному рівні обгрунтовано процес духовного розвитку підлітків, який зумовлює послідовне та повноцінне формування ієрархічної системи компонентної структури духовності сиріт. В послідовному формуванні зазначених складових підліток набуває нового позитивного досвіду, що сприятиме розвитку й актуалізації духовного потенціалу.

Виділені етапи процесу духовного розвитку підлітків-сиріт, компоненти духовності та критерії дозволяють прогнозувати рівні сформованості розглянутих компетенцій та здійснити вибір діагностичних засобів, а також відстежувати динаміку сформованості етапів та компонентів духовності в процесі духовного розвитку підлітків-сиріт у закладах інтернатного типу.

Таким чином, теоретично обгрунтовані методологічні основи психологічної моделі процесу духовного розвитку підлітків, які проживають у закладах інтернатного типу, потребує емпіричного підтвердження.

1. Ломов, Б. Ф. (1984). Методологические и теоретические проблемы психологи. Ю. М. Забродин, Е. В. Шорохова (Ред). М. : Наука.

2. Основні інтернет-терміни та поняття. Походження слова «принцип» . Дизайн нового мира (2018). Взято 3: http://design-for.net/page/princip.

3. Павлик, Н. В. (2015). Психологія гармонізаиії характеру в юнацькому віці: Монографія. К.: Логос.

4. Павлик, Н. В. (2017). Психологія гармонізаиії характеру в юнащькому віџі. (Автореф. д-ра психол. наук). НПУ ім. М. П. Драгоманова, Київ.

5. Панок, В. Г. (2006). Проблема визначення методологічних основ практичної психології. К.: Ніка-Центр.

6. Петрочко, Ж.В. (2018). Сутність та напрями соиіально-педагогічного забезпечення прав дітей. Матеріали конференції «Актуальні питання соціально-педагогічної роботи в закальноосвітніх навчальних закладах». Ел. збірн. наук. праць. Український електронний психолого-педагогічний ресурс. Взято з: http://www.psyh.kiev.ua/.

7. Помиткін, Е. О. (2015). Духовний потениіал особистості: психологічна діагностика, актуалізаиія та розвиток: посібник. Київ: «Внутрішній світ».

8. Помиткін, Е. О. (2009). Психологічні закономірності та механізми духовного розвитку дітей $і$ молоді. (Дис. д-ра психол. наук). НПУ ім. М.П. Драгоманова, Київ.

9. Рибалка, В. В. (2003). Методологічні питання наукової психологї (Досвід особистісно центрованої систематизаиії категоріально-поняттєвого апарату): навч.-метод. посіб. К.: Ніка-Центр.

10. Савчин, М. В. (2013). Духовна парадигма психологіï: монографія. К.: Академвидав.

11. Уманская, Е. Г. (2013). Развитие личности в условиях депривации: Монография. М.: Прометей.

12. Шипицина, Л. М. (2000). Комплексное сопровождение и коррекция развития детей-сирот: социальноэмоциональные проблемы. Л. М. Шипицыной, Е. И. Казаковой (Ред.). СПб.: Институт специальной педагогики и психологии. 
1. Lomov, B. (1984). Metodologicheskiye i teoreticheskiye problemy psykhologii [Methodological and theoretical problems of psychology]. Yu. M. Zabrodyn, E. V. Shorokhova (Red.). M.: Nauka. (rus).

2. Osnovny internet terminy ta ponyattya. Pokhodjennya slova «pryntsyp» (Elektronnyy resurs) (2018). [Basic internet and concepts. Origin of the word «principle». Dyzayn novoho myra. Retrieved from: http://designfor.net/page/princip. (ukr.).

3. Pavlyk, N. (2015). Psykholohiya harmonizatsiyi kharakteru v yunatskomu vitsi: monohrafiia [Psychology of harmonization of character in youth: monograph]. K.: Lohos. (ukr.).

4. Pavlyk, N. (2017). Psykholohiya harmonizatsiyi kharakteru $v$ yunatskomy vitsi. [Psychology of the harmonization of character in youth]. (Avtoref. na zdobuttya nauk. stupenya dok. psykhol. nauk) [Author's abstract for the degree of Doc. of Psychol. Sciences]. NPU im. M.P. Drahomanova. Kyiv. (ukr.).

5. Panok, V. (2006). Problema vyznachennya metodolohichnykh osnov praktychnoyi psykholohiyi [The problem of determining the methodological foundations of practical psychology]. K.: Nika-Tsentr. (ukr.).

6. Petrochko, Z. H. (2018). Sutnist' ta napryamy sotsial'no-pedahohichnoho zabezpechennya prav ditey. Materialy konferentsiyi «Aktual'ni pytannya sotsial'no-pedahohichnoyi roboty v zakal'noosvitnikh navchal'nykh zakladakh». El. zbirn. nauk. prats [Essence and directions of socio-pedagogical support for children's rights: Materials of the conference "Actual questions of social-pedagogical work in quench educational institutions"]. Ukrayinskiy elektronniy psykholohopedahohichniy resurs. Retrieved from: http://www.psyh.kiev.ua. (ukr.).

7. Pomytkin, E. (2015). Dukhovnyy potentsial osobystosti: psykholohichna diahnostyka, aktyvizatsiya ta rozvytok: posibnyk [Spiritual potential of the person: psychological diagnostics, activation and development: manual]. Kyiv: «Vnutrishniy svit». (ukr).

8. Pomytkin, E. (2009). Psykholohichni zakonomirnosti ta mekhanizmy dukhovnoho rozvytku ditey $i$ molodi. [Psychological patterns and mechanisms of spiritual development of children and youth]. (Dys. d-ra psykhol. nauk) [Thesis of the doctor of psychological sciences]. NPU im. M.P. Drahomanova. Kyiv. (ukr).

9. Rybalka, V. (2003). Metodolohichni pytannya naukovoyi psykholohiyi (Dosvid osobystisno tsentrovanoyi systematyzatsiyi katehorial'no-ponyattyevoho aparatu): navchalno-metodychnyy posibnyk [Methodological issues of scientific psychology (Experience of personally centered systematization of categorical-conceptual apparatus): educational and methodical manual]. K.: Nika-Tsentr. (ukr).

10. Savchyn, M. (2013). Dukhovna paradyhma psykholohiyi: monohrafiya [Spiritual paradigm of psychology: monograph]. K.: Akademvydav. (ukr).

11. Umanskaya, Ye. (2013). Razvitiye lichnosti v usloviyakh deprivatsii : monografiya [Personality development in the conditions of deprivation: monograph]. M.: Prometey. (rus).

12. Shipitsina, L. (2000). Kompleksnoye soprovozhdeniye i korrektsiya razvitiya detey-sirot: sotsialno-emotsionalnyye problemy [Comprehensive support and correction of the development of orphans: social and emotional problems]. L. M. Shipitsinoy, E. Y. Kazakovoy (Red.). SPb.: Institut spetsialnoy pedahohiki i psikhologii. (rus).

\section{Alina Parasiei-Hocher \\ TO THE CONSTRUCTION OF THE PSYCHOLOGICAL MODEL OF SPIRITUAL DEVELOPMENT OF ORPHANS AT BOARDING SCHOOLS}

The article is devoted to one of the topical problems of modern psychological and pedagogical research in the field of spirituality and spiritual development of personality. The state of development of research on the spiritual development of personality and psychological support of orphans and children deprived of parental care encouraged the theoretical substantiation of the psychological model of the process of spiritual development of adolescents - pupils of state institutions of institutionalization. It is argued that for the spiritual formation and realization of positive emotional-sensory states, cognitive interests, value orientations of orphans in adults age, it is expedient to apply a spiritual and personal approach that allows us to consider the spiritual development of adolescents as a process of interaction between external (socio-psychological) and internal (individual psychological) characteristics of orphans in boarding schools. The author focuses on the definition and justification of methodological principles: the principle of hierarchy (the formation of an orderly system of structural components of spirituality), positivity (the value of the personality of adolescents, the emphasis on positive experience and orientation towards the future) and the principle of spiritual personal interaction (creating an atmosphere of trust, cooperation "psychologist-child"). According to the spiritual-personal approach, the mechanisms of spiritual development of orphans (identification, decentralization, reflection, transcendence and awareness of existential unity), as well as stages of the process of spiritual development of orphans are defined: the stage of mastering spiritual feelings; spiritual knowledge and self-knowledge (reflection); spiritual self-improvement (the formation of moral and spiritual deeds); stage of the direction of spiritual growth (orientation to spiritual ideals, meanings, values). There are four components of spirituality: emotional-sensory, cognitive, moral-behavioral and value-semantic. It is noted that each of the stages in the process of spiritual development of adolescents is aimed at forming a certain component of spirituality. It is pointed out that the basic idea of the psychological model of the process of spiritual development of orphans in adults age is that the stages and components of spirituality are interrelated: in the process of forming one stage and component, the formation of the next occurs. The problems and perspectives of further research of spiritual development are determined. 
Keywords: adolescence, psychological peculiarities of orphans, spiritual development, principles of the spiritually oriented approach, stages of the process of spiritual development, psychological model. 